\title{
重複癌 の一剖檢例
}

\section{專攻生時 岡 精 一

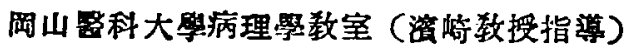

\section{緒言}

原發性多發腫瘍は以前考へられた栚に稀な ものではない，然し原没性癌属の多發に至つ ては其の頻度は極めて少ん. 余は最近此の稀 な重椱癌の 1 剖檢例去經驗した・向本例は郜 林上，㷉胛部肉腫と診缽されたが，剖檢によつ て原添性肺臟癌の肩胛部榑移であつた興味あ る症测である。

\section{賽 驗 例}

小○棈○男 57 歲 剖檢番號 973 .

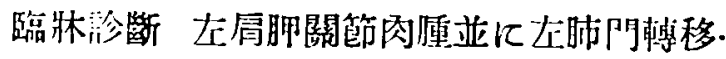
家族歷 近斍者に癌で死亡したものはない。 既往症 淋疾並に筋炎老經過した。

略病麼 昭和 21 年 10 月中旬加方左肩胛關 節部に輕度の疼痛を覮え，次第に佰强し左上

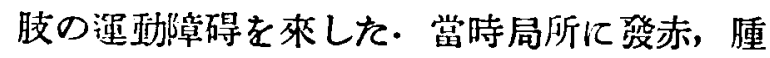
脹，熱滛等は無く，同年 12 月中旬から該部腫

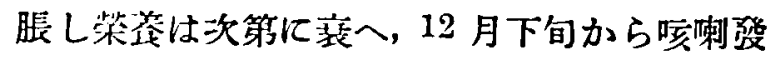
作が始つた。昭和22 年 1 月 8 日當大學三宅 外科に入院加療を行つたか，左原胛關節部の

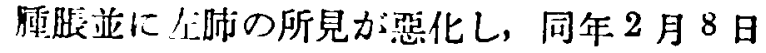

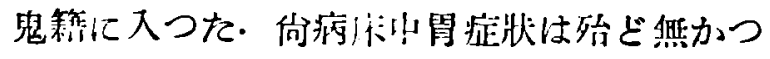
た.

病理組織的診路

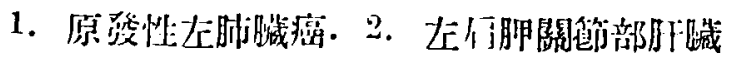

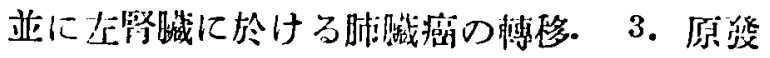

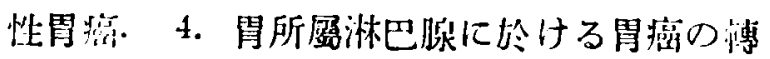

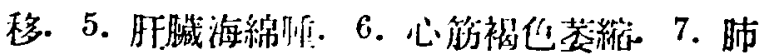

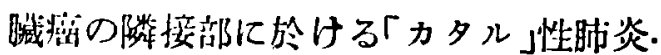

剖 檢 所見

1) 㘬眼的所見 身長 $150 \mathrm{~cm}$, 體重 $31 \mathrm{~kg}$,



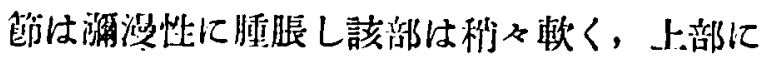
一錢銅貨大の黑裀仙な施皮が附着してる己.
且つ2 個の手石創がある・之を卵開すると黄

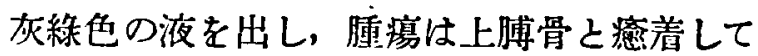
みる.開檢すると腹腔には藷變を認めなん。 胸膑を開检すると左肺屋部は第 1 , 第 2 肋骨

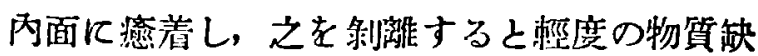
損が起る. 右肺尖にる亦輕度の杪着がある.

心臟 大さ當尾手挙大, 周圍 $22 \mathrm{~cm}$, 重さ $212 \mathrm{~g}$.

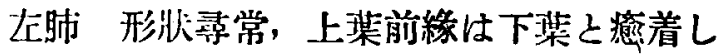

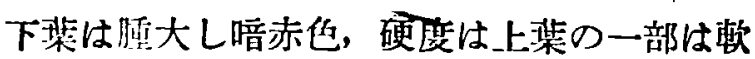
化して居るが他は硬い下装は彈力性軟であ ろ. 割面：上萑屋部外挠方は一部空洞を形 成し，他は充䁈性で灰白色である. 空洞內に 黄褐色の液を容れる・肺門は淡黄灰白色で硬 く, 間質に沿つて放線狀に灰白色の浸潤が阨 屋部に向つて放散する.肺門淋巴腺は拇指頭 大に腄脹して逽だ硬い. 氣管支內に黃褐色粘 稠な液が少量あり, 粘膜の細血管は輕度に充 盈してるる。

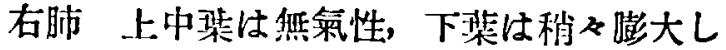
色は暗赤色・割面：下菲は秒ぬ血量に富み 盟すると血液を泥じた泡沫のある液體が少量

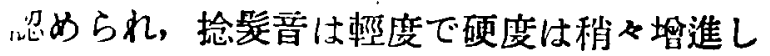
て居る。

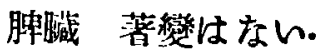

朋獩 形態㜔常, 重さ $130 \mathrm{~g}$, 右紧は外上部 は一錢銅货大の熙色の部分があり少し陷没し てわる・該部の割面は咥赤色で少量つ血液が

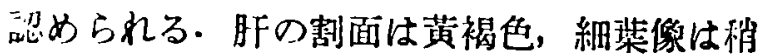
々不朋瞭である。

崏蘶異常を認めない。

左腎 重さ $150 \mathrm{~g}$, 裴面（前面）に一個の果 粒大の黄色斑點がある(腫痛の轉移). 其の他 には著變は筫い。

右腎重さ $160 \mathrm{~g}$ ，穖維辜の制離は困難で 一部に物啠缺損がある.下部前面に小豆大の 透明な液を容れた䨩が 3 個ある。 


\section{膵臟著變は變められない。}

顽部睵器に異常を認めをい。

胃 幽門に近い粘瞙に拇指頭大の物質缺損 がある. 周圍は硬く膨隆し, 灰白色で所ネに

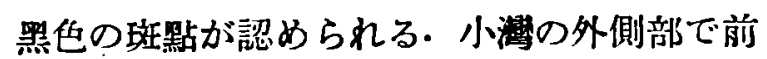
記潰場の近くに拇指頭大の淋巴腺が 1 個あ る. 割面は膠样癌の轉移を思はせる。

晹 所ふに箸血があり，一部には出血斑が 認められる。

骨盤諸孀器に異常を認めない。

2) 顯微鏡的所見

心驖 心能は稍々萎縮し「リポフスチン」を 中等:量に認める。

脾践 溜胞は萎縮し, 中心動脈壁は肥厚し， 脾洞の影血は可成强い。

肺臟後述の肺膘㾤部以外は肺策腫の像で ある・

胃 後述する腫瘍部以外は著變を認めない。 小腸 粘膜下靜脈に麓血が認められる.

大腸 粘膜下靜脈は著明に磿血し, 一部の 浭胞には輕度の腫脹がある。

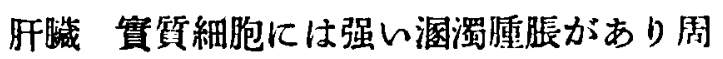
灙性脂肪化が輕度に認められる・一部には海 總腫が存在する。

左局胛部の腫瑏 實質細胞は一般に大型の 扁平な多角形を呈し, 細胞界は此較的明膫で ある・㤥は類圆形，不整楕圆形等で一般に大 きい. 核小體及び核膜は不朋膫で「クロマチ ン」は稍々硒漫性である. 可成多数の單侅性 及び多核性のE態細胞が認められ，核有綵分 裂が小数にある・分裂像に珙常が認められる。 惯質細胞は多くは細胞巢を形成し，基芘とは 可成明瞭な境をしてるる。然し一部では稍々

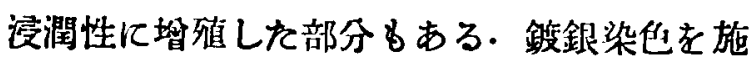
行したが實質細胞問に咾銀瀻維は狳り認めら れなかつた・基筫は可成多量にあり，小數の 圆形細胞が散在してるる.以上の所見は次に

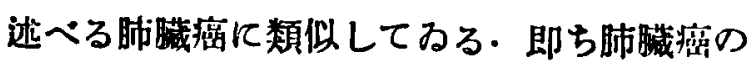

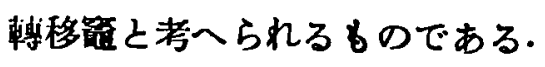

肺腫瘍部大體前記に類似してるるが廣い

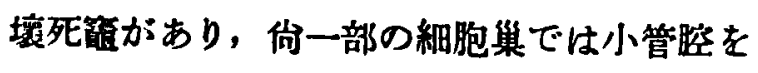
形成してるる細胞は, 稍々圆柱形を呈してる
るが大多数は阴平上佊椂である・又基質が甚

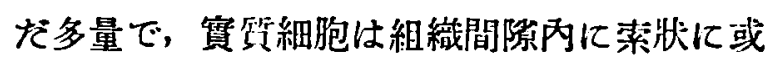
は散在性に現はれて硬性癌の像を呈してるる 所もある，腄㾤に接してるる肺實質は，廣く 「カタル性肺炎を起してるる。

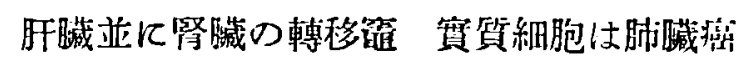
の賽缶細胞に類似してるるが，その多型性は 左程虽くはなくて, 算所に比较して些貎が少 量である。

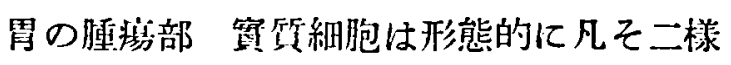
の細胞に分けることが出來る・大多数は小圆 形で，原形饭に蝔だこしくて核も小圆形で 「クロマチン」富んでるる・小部分の實毁縕 胞は秒々大きくて顆粒を充してるる・此の㥞 な二㩐の寞啠細狍は索狀又は不整類圆形で境 界の銳利な細胞集を形成して，大形細胞の一 部では小量の粘液を形成してるる。置斦細胞 は粘旬是の基底部力。粘膜下縕織老浸閏して更



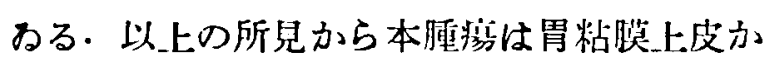

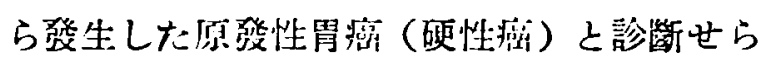
れる。

胃所屬淋巴腺 胃壁同樣の實印細胞が，冭 實性な細胞巢を形成してるる部分も認められ つ. 然し多くの部分では多量の粘液を形成し て膠梯癌の像を是してるる.

\section{總括並に考案}

原没性阿游の多發頻度は, Holmqvist 及び Nelsonに依ると4000の剖檢例中 22.5\%の割 で, Egli は 4765 剖檢例中 $5.5 \%$ の割で, Harbitz 3613 剖检例中 $2.8 \%$, Puhr は 6718 剖 檢例中 $3.3 \%$ の割で原發性蕾㿇の多發を認め てるる・此の㥞な意味の臛樑の多發は稀では

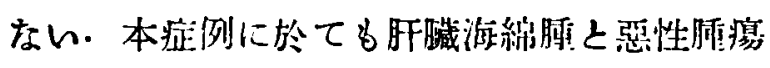
とが併存してるる.反之同一储體で 2 㑑以上. の原發性惡性腄演の發現は甚だ稀で, Hilgert

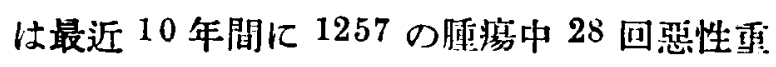
複䏦(2例の白血病を算入してるる), Warren 及び Gatesは1932 年までの文献に現はれた 惡性腫演の多發症例者葛集して，之に依ると 794 例, 之に Owen の 143 例, Major の 189 
例, Ward の93 例及び彼等の觀察した 40 例 を加へて, 同年までに 1259 例の惡此腫㾤の重 複例を數へた・参考に氏の一統計を擧げる之 第 1 表の樣に惡性腫演の重椱は全剖檢數に對 して總て 1\% 以下である. 而して惡性腫廈重 複の中で, 最も重要なものは癌腫の重複であ る.V. Hansemann は 1000 例以.上の癌腫中
5 例を舉げ，Redlichは 456 例の癌腫中 2 例 を舉げ, Siebkeは1\% 以下であると・林氏は 110 例の癌腫中唯だ 1 例, Müller, Provence, Bernhard は 5782 例の剖检中 $0.17 \%$ の割之 云ひ，其の他諸氏の報告があつて賞初考へら， れた程珍奇なるのではないが，倘且甚だ稀な 事柄でちる.岗数室に於ても剖檢數997 例中

第 1 表惡性腫疹重複の頻度に關する統計（Warren \& Gates に依る）

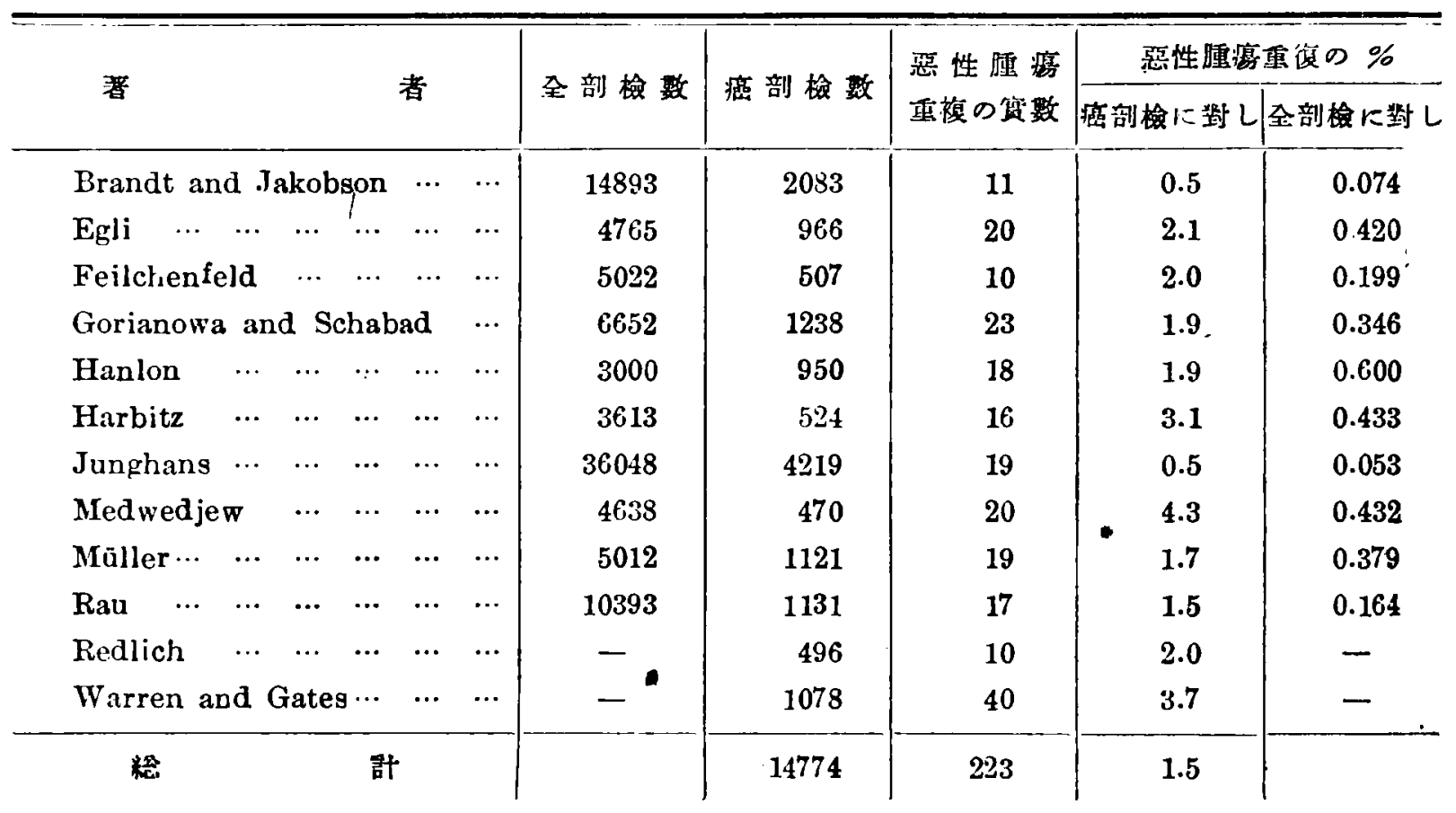

㿋腫 142 例であつて，內重複㾋は 4 例のみで ある.队3 例は既に河村氏(2 例) 及び中村氏 （1例)の垠告した所である.

抑々重複㾔を問題にしたのは Billrothであ

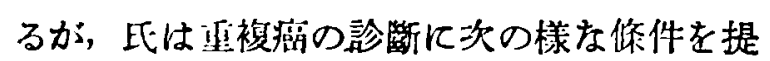
唱した.

1）夫ょの腫瘍は，夫↔異つた組織的權造 を示さ极ばならない。

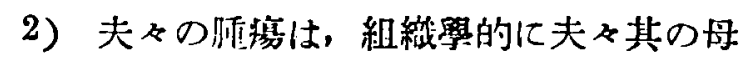
地から頱かれたものである事が登朋されるを 然する。

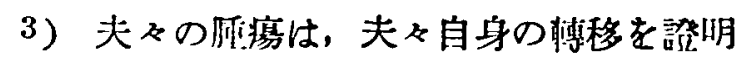
しなければならない。

てのBillrothの猃明は, 古典的の意味を有 するに過きないのであるが，その後 Goetze は此の偦件に批判を加へて，之に代る次の保 件を㦛方てるる・即ち

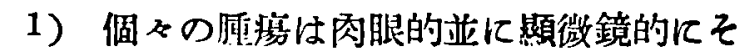
の生じた場所に，日常見られる原發癌の像を 呈さねばならない。

2) 間知の棘移，移殖等の法则に從つて,一 方の臛序が他方のものに從䙓的のものでない 事が登朋されることを要する。

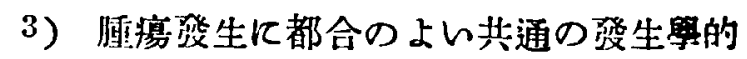
の葓常或は病因學的の原因が伱する場合, 及 び別々の榑移の證明される場合は多發の想定 は支持を受ける。然しPuhr に依るとての Goetze の條件も完全なるのと見做されない。 Puhr, Warren 及び Gates, 久留等は此等の 條件の完備之云ふ事よりも，個々の隀演が城

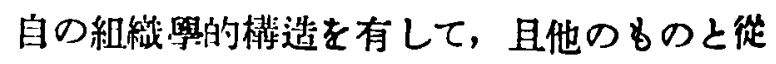

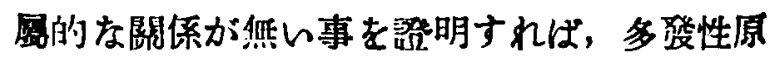
没㾞と診断して良いと云ふ教に傾いてみる。

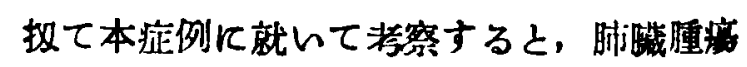


は左上下雨集に有り，上葉の一部には空洞孝 形成して左局朋關笁部に最大轉移を，更に肝

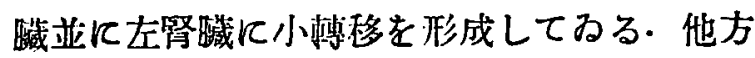
胃の董瘍は胃幽門部の近くに有り，挴指頭大 の物質缺損があり周園は硬く嗃隆してるる.

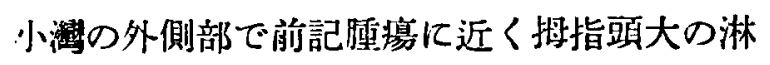
巴腺慱移が 1 個認められる。

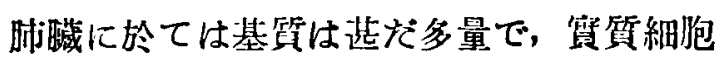
は基質间隚內に禁状或は散在性に現はれて, 實質細胞は一般に大型の平履な多角型を是し て細胞の境は比較的明膫である・向細胞巢の 一部では小管腔を形成してみて，之を圍んで みる細胞は稍ぬ圆柱形を是してるる。核は類 圆形，不整指圆形等で一做に大きい. 核小心 及び㤥膜は不明瞭で「クロマチン」は稍々确漫 性である. 又可成多數の單㤥性及び多㤥性の 巨態細胞が認められ，核有線分裂は少䍩で分 裂像に異常がある. 更に肺臟癌は左局胛鹠笷 部, 朋歲並飞左腎歲に前記組織像を有する轉 移を形成してるる。

胃腫瘍の實質細胞は二樣の細胞から出來て 大多數は小圆形で原形質にそしく，核も小圆 形でっクマチン」に富み, 小部分の實質細胞 は稍々大きく，原形質は顆粒で满され淡調で 「ェオヂン」に可成良く染色される・此の㥞な 2 種の細胞は索狀又は不整類圆形の境界銃利 な細胞条を形成して大形細胞の一部では少量

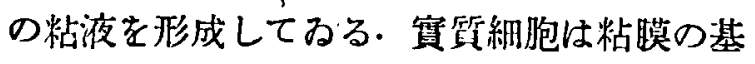
底部から粘膜下組織を浸潤して更に繁層の組

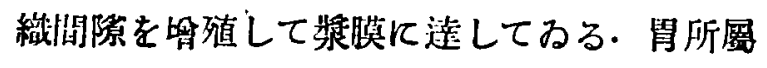
淋巴腺に同樣の样造学有する博移を認める。

以上の所見から本症例は脯胞上皮から設生 した肺裁癌並に胃粘膜から發生した胃癌が認 められ，各々組䊼學的構造を異にして各く槫

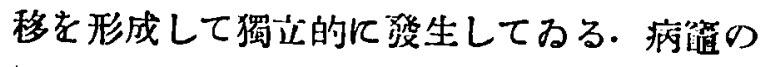
新蕉から見て恐らく前者が先潑癌で，後者は。 後に發生した重複癌である。

次に重復癌の分類に，關する文献を見ると， 之亦多数で其の 2,3 學げると第 2 裴及び身 3 表の様である. 最近總說を行つた Warren 及び Gates は第 3 表の桹な分類を探用してな る.ての統計で制る様に惡性喠㾤の多發中，
第２表 惡性腫韵或は癌腫の 重複の分類

Hansemann (1904) k依る

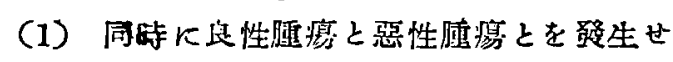
了埸合

（2）同一器官に网種の厘源を發生せる場合

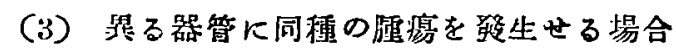

Harbitz (1915) に依る

(1) 同一器官系統比登生せる同種の腫䭲

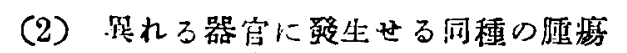

(3) 罚れる器官火發生せる異種の腯場

(4) 同一器官に路生せる数個の非定型的原 源. 特に Carcinosarcoma

第 3 表 惡性腄煌或は癌腫の重䙉の分類 (Warren 及び Gates に依る 1932)

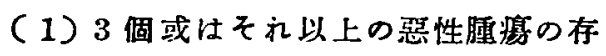
在せる症例

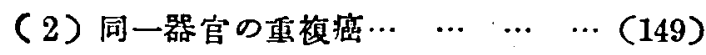

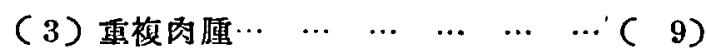

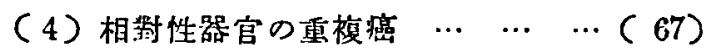

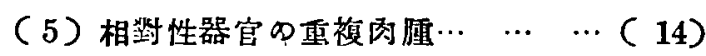

(6) 同一系統器官の重複癌………

(7) 筧種系紩器官の重被癌…

(8) 同一器官の Carcinosarcoma …(46)

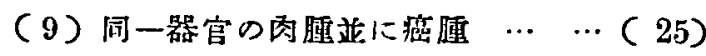

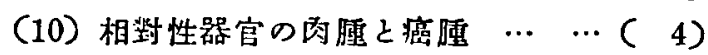

(11) 同一系統器官の肉腫々癌腫 $\cdots \cdots(3)$

(12）暴種系統器官の肉埂之癌画……(48)

註括弧內に記したのは其の症例數である.

最も屡及見られるのは癌腫の多發で, 癌腫の 多發した場合Ribbertは次の 2 つの館疇に分 けた・即ち

1）共通の原因により同一器官或は同一系

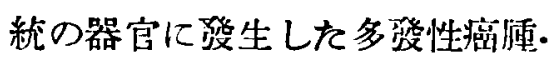

2）共通の原因之認める事の出來るるのは なく，同一系統の器官或は異種の系統の器官 几發生した多筂性癌腫.

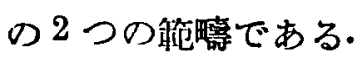

双て多發性原發噋の原因に關して既に1896 年Walter は (1) 㾔細胞の移殖. (2) 刺戟の

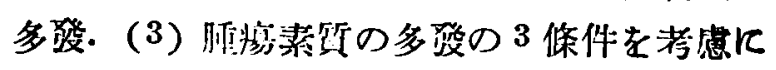
入れるできであるとして居るが，本症例に於

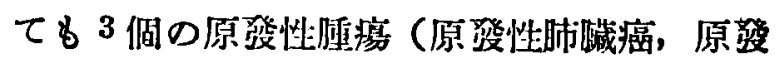


性胃括，並に朋臟海綿腫）の存在してみる事 賽から，先天性の婳瘍素沂と云ふものが特に その一因子と获へられる。

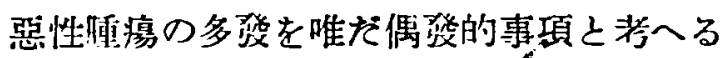
上りは，誰もが何か內因的素因の潜在を将人 る所である.Warren 及び Gates は單一癌脽 の出現揫之重複癌胢の出現率の此較から，重 襩㿋は單に偶然に依つて 2 個のものか京時に

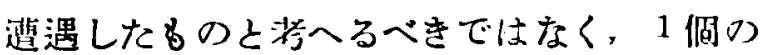

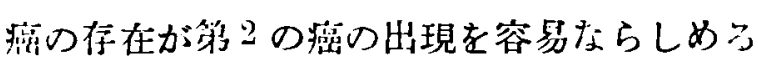
状態を招隶すると云ふ結論に達してるう・成 程设罗の統計的數宇のみからでは，彼等の主 張する梯な結論に達するが，重複癌の總ての

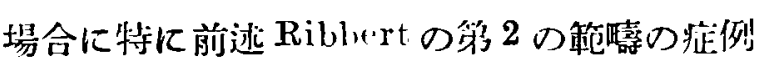

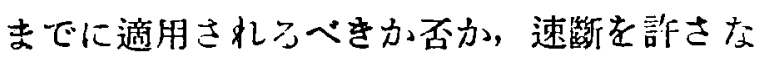
い所である.

腫演發生の成团に種ねあるが，その一つと

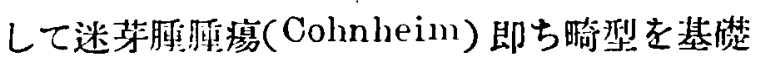
として令生する先天性原因によるるので，此

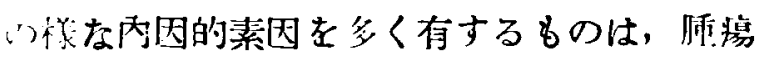

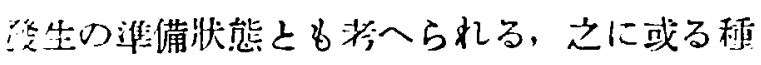

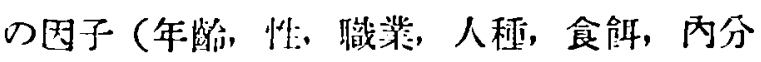

\section{主 要 文 献}

I) Hansemann, Z=chr. f. Krebsforschung, Bd. 1, S. 181, 1904. 2) Redlich, Zschr. f. Krebufurchung, B.l. 5, S. 2 r.1, 1907. 3) Ribbert, Das Karzinom des Menschen, S. $36 \overline{\text {, }}$ 1911. 4) Gretze, Zchr. f. Krebsforschung, Ba. 13, S. 2s1, 191:. 5) Harbitze, F., Zierrler Beiträge, Bu. (:2, S. 503, 1910. 6) Sieble, II., Zschr. L. Krebstur-chung, Ba. 2:3, S. Ge, 1920. ij Puhr, L., \%chr. f. Krebsforschumer, Bd. $24, \leq .1,1927$. 8) Müller, Provence, Berniard, Zachr. A. Krebsforschung, Bd. 48,
泌自律神經系の戀化,刺戟等ぬ) が加つて, 腫 湢の多發延いては癌喠の多發る将へ得る所で ある。

即ち本症例汇就て見ると，患者は內因的素 因を有する_に先發癌(肺臟癌)の發有が後發 癌 (胃癌)を諲發したものか之思考せられる。 然し多設癌の原因の決定は, 將來の研究に侯 つ所が多h.

\section{結語}

1) 临教空 997 例の剖檢例中 4 例 (0.4\%) の原發性重椱虂を認めた。

2）体例は肝裁海綿崏及び原發性肺㙎癌上

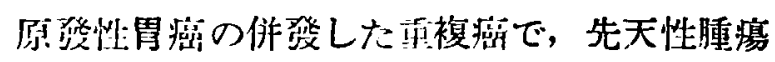
素因の永在を思はしめる。

3）肺陯癌は肺胞_上皮から發生して左肩胛 關節，肝瀻並に左腎臟に轉移を形成し，胃癌 は胃粘膜上皮から發生して胃所圆淋巴腺に轉 移を形成してるた症例である・佁肩胛關節の

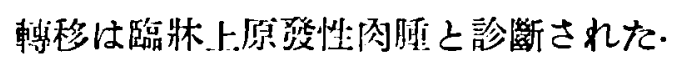

据筆するK臨んで恩師溜崔教授の御愁篤なる御 指導と御校閶に對して謝深する。

S. 26, 1939. 9) Warren and Gates, The American Journal of Cancer, Vol. 16, P. 1358, 1932. 10) Holmqvist und Nelson, Zschr. f. Krebsfurschung, Bd. 47, S. 257, 1938. 11) 河村九市 九，岡山學會雜誌，第 40 年，第 11 躆，昭和 3 年.

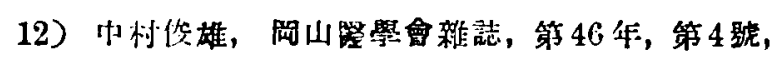

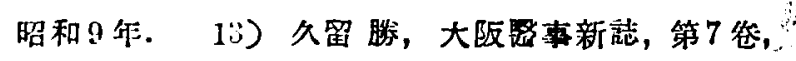
昭和 11 件. 14) Hermann, Hilgert, Zschr. f. Krebsforschung, Bd. 49, S. 390, 1904. 15) Scheidegger, Ziełler Beiträge, Bd. 104, S. 402, 1940. 